\title{
Hubungan Kelekatan Terhadap Ibu dan Penyesuaian Diri pada Remaja Disabilitas Fisik
}

\author{
Azza Febria Nuraini ${ }^{1}$ \\ Fakultas Psikologi, Universitas Muhammadiyah Malang \\ e-mail: ${ }^{1}$ azfeni@gmail.com
}

\begin{abstract}
As social beings, adolescent with physical disability are required to interact with their social environment to fulfillment and achieve inner tranquility with its surroundings. Limitations in adolescent with physical disability often make them feel inferior, especially if the response in the environment does not accept their physical condition, it will causes psychological problems and make adolescent with physical disability tend to withdraw from social environment. Adolescent attachment to the mother is predicted to increase self-esteem and become resilience in adolescent with physical disability. The purpose of this study to determine the relationship of attachment to the mother and adjustment in adolescent with physical disability. This research is a correlational quantitative research with sample of 56 adolescent with physical disability aged 12-21 years old. Methods of data collection using total sampling technique with adolescent attachment scale to mother and adjustment and analyzed using product moment pearson correlation. This study shows $(r=0.815, p=0,000)$. Thus, it can be concluded that there is a significant positive relationship between attachment to the mother and adjustment in adolescent with physical disability.
\end{abstract}

KEYWORDS Attachment to mother, adjustment, adolescent of physical disability

CITATION Nuraini, A. F. (2018). Hubungan kelekatan terhadap ibu dan penyesuaian diri pada remaja disabilitas fisik. Cognicia, 6, (1), 22-36.

Secara hakiki, manusia merupakan makhluk sosial yang tidak dapat hidup sendiri. Maka dalam hidupnya ia membutuhkan penyesuaian diri agar mampu berinteraksi secara baik dengan individu lain. Penyesuaian diri yang baik terjadi jika individu selalu dalam keadaan seimbang antara tuntutan dirinya dengan lingkungannya. Penyesuaian diri ini diperlukan individu untuk mempertahankan eksistensinya dalam mengadakan relasi untuk memuaskan tuntutan sosial. Penyesuaian diri dibutuhkan pada semua individu, tidak terkecuali pada individu yang memiliki disabilitas fisik.

Disabilitas fisik, menurut Effendi (2006), merupakan kelainan yang terjadi pada salah satu atau lebih organ tubuh bagian tertentu yang menyebabkan berkurangnya fungsi fisik organ tubuh sehingga penderitanya mengalami kesulitan dalam beraktivitas. Ada beberapa jenis disabilitas fisik, yaitu alat fisik indera seperti kelainan pada indera pendengaran (tunarungu), indera penglihatan (tunanetra), kelainan pada fungsi organ bicara (tunawicara), dan alat motorik tubuh (tunadaksa).

Menurut Badan Pusat Statistik (BPS) Kota Malang pada tahun 2016, ada sekitar 1397 penyandang disabilitas di Kota Malang dengan jumlah laki-laki sebesar 755 dan 


\section{ATTACHMENT TO MOTHER, ADJUSTMENT, ADOLESCENT OF PHYSICAL DISABILITY}

berjenis kelamin perempuan sebesar 642. Data ini menunjukkan bahwa jumlah penyandang disabilitas di Kota Malang masih tinggi.

Disabilitas fisik terjadi pada rentang usia bayi hingga usia remaja. Disabilitas yang terjadi pada masa remaja menjadi bahasan yang penting, karena dalam masa ini, remaja akan mempersiapkan diri memasuki kehidupan dewasa. Rentang usia remaja menurut Hurlock (dalam Al-Mighwar, 2006) adalah pada usia 12-21 tahun.

Salah satu hal yang menjadi tuntutan bagi remaja adalah upaya untuk menemukan dan mengatasi tekanan dalam mencapai pribadi yang sehat. Pada masa remaja, penyesuaian diri merupakan proses yang cukup penting, karena pada masa ini terjadi perubahan sosial, peran, dan perilaku. Ingersoll (dalam Agustiani, 2006) mengatakan pada masa ini, remaja mulai melepaskan diri secara emosional dari orang tua dalam rangka menjalankan peran sosialnya yang baru sebagai orang dewasa. Fenomena yang terjadi saat ini pada remaja disabilitas fisik yaitu sulitnya membangun jati diri karena hambatan yang dimiliki. Suharmini (2007) mengatakan remaja dengan disabilitas fisik akan mengalami keadaan psikologis sikap gugup dalam berbicara, kurangnya semangat, timbulnya rasa kecewa karena kegagalan, dan rasa putus asa. Selain itu, adanya pemikiran-pemikiran negatif bahwa remaja disabilitas fisik adalah remaja yang tidak memiliki potensi membuat mereka memerlukan lebih banyak usaha untuk menyesuaikan diri.

Menurut Ali \& Asrori (2012,) penyesuaian diri diartikan suatu proses yang mencakup respon mental dan perilaku yang diperjuangkan individu agar berhasil menghadapi kebutuhan-kebutuhan internal, ketegangan, frustasi, konflik, serta untuk menghasilkan kualitas keselarasan antara tuntutan dari dalam diri individu dengan tuntutan luar lingkungan individu berada. Terdapat studi di lapangan pada remaja disabilitas fisik yang memiliki penyesuaian diri negatif, yang dilaksanakan pada tanggal 2 Juni 2017 bertempat di SMALB X di Kota Malang. Studi tersebut melibatkan subjek berinisial S, seorang penyandang tunarugu dan D seorang tunanetra. Perilaku yang tampak di sekolah pada keduanya yaitu pasif, sulit berinteraksi dengan teman, dan gugup saat berbicara dengan orang lain. Melalui hasil wawancara dengan subjek dan significant other, diketahui kedua subjek memiliki hubungan yang negatif dengan orang tua, seperti kurang komunikasi dan dukungan. Studi berikutnya bertempat di SMALB X di Kota Malang pada tanggal 2 Juni 2017 dengan subjek berinisial M dan A penyandang tunanetra dan tunadaksa. Perilaku yang tampak di sekolah, keduanya aktif, mudah berbaur, percaya diri. Melalui hasil wawancara dan significant other diketahui keduanya memiliki hubungan yang positif dengan orang tua terutama ibu, baik dalam hal komunikasi dan dukungan. Ini menunjukkan bahwa tidak semua remaja disabilitas fisik memiliki kelekatan yang baik dengan orang tuanya. Kelekatan ini juga diduga akan mempengaruhi penyesuaian diri pada remaja disabilitas fisik.

Hasil studi di lapangan menunjukkan bahwa keluarga memegang peranan penting dalam penyesuaian diri remaja. Sejalan dengan penelitian Enung (2006) yang mengatakan bahwa pengaruh lingkungan keluarga seseorang merupakan hal yang sangat penting bagi keberhasilan penyesuaian diri orang tersebut. Dari sekian banyak faktor yang mempengaruhi penyesuaian diri, faktor lingkungan keluarga menjadi yang sangat penting, sebab keluarga merupakan media sosialisasi bagi seseorang, terutama anak-anak. 


\section{Cognicia}

http://ejournal.umm.ac.id/index.php/cognicia
ISSN 2658-8428

, Vol. , No. , -

Interaksi keluarga antara anak dan orang tua akan membentuk suatu ikatan emosional yang dinamakan kelekatan. Menurut Berk (2005), kelekatan atau attachment adalah suatu ikatan afeksional yang kuat, yang ditujukan pada orang-orang tertentu dalam kehidupan yang membuat individu merasa senang dan bahagia ketika berinteraksi dan merasa nyaman di dekat mereka pada saat tertekan. Eliasa (2011) menemukan bahwa ibu menduduki peringkat pertama sebagai figur lekat utama anak. Ibu biasanya lebih banyak berinteraksi dengan anak dan berfungsi sebagai orang yang memenuhi kebutuhannya serta memberikan rasa nyaman. Gunarsa \& Gunarsa (2006) mengatakan ibu lebih banyak memiliki peranan dan kesempatan dalam mengembangkan anak-anaknya. Hal ini dikarenakan ibu memiliki lebih banyak waktu yang digunakan bersama anak-anaknya. Selain itu, ibu yang selalu datang saat anak menemui kesulitan, ini dapat terlaksana jika ibu memainkan peranannya yang hangat dan akrab, melalui hubungan yang berkesinambungan dengan anaknya.

Orang tua yang memiliki anak berkebutuhan khusus dituntut untuk terbiasa menghadapai peran yang berbeda dari sebelumnya (Miranda, 2013). Penelitian Howe (2006) menemukan bahwa orang tua yang memiliki anak berkebutuhan khusus memiliki beban berat, baik fisik maupun mental. Beban tersebut membuat reaksi emosional di dalam diri ibu sebagai figur pengasuh yang utama. Kelekatan yang terjadi antara orang tua dan anak adalah hasil dari perilaku dan interaksi sehari-hari. Penelitian ini juga menemukan bahwa temperamen anak atau adanya kecacatan pada anak juga dapat memengaruhi perkembangan kelekatan. Selaras dengan penelitian yang dilakukan Lopez (2013) mengenai kelekatan ibu dengan anak disabilitas, menunjukkan kebanyakan ibu dengan anak disabilitas memiliki kelekatan serta penilaian negatif pada anak mereka daripada ibu yang memiliki anak normal. Selain itu, ibu dengan anak disabilitas memiliki ungkapan emosi yang negatif dibandingkan saudaranya yang tidak mengalami disabilitas. Emosi negatif tersebut timbul karena stres orang tua dan beban pengasuhan serta perilaku anak.

Penelitian Perkins (2002) tentang kelekatan ibu terhadap anak berkebutuhan khusus dan harga diri menunjukkan kelekatan antara ibu dan anak akan memengaruhi harga diri. Anak yang memiliki kelekatan yang hangat cenderung menunjukkan harga diri yang lebih tinggi, sedangkan gaya kelekatan menghindar maupun cemas mengakibatkan anak cenderung memiliki harga diri yang lebih rendah.

Ma \& Huebner (2008) menemukan bahwa kelekatan anak yang terjadi pada ibu akan berkembang seiring waktu, tidak terkecuali pada masa remaja. Kelekatan pada masa remaja merupakan kelanjutan dari kelekatan yang dikembangkan oleh anak dengan pengasuh selama masa awal kehidupan, dan akan terus berlanjut sepanjang rentang kehidupan. Allen \& Land (1999) mengatakan bahwa kelekatan pada masa remaja dengan orang tua akan berbeda dengan kelekatan pada masa anak-anak, baik perilaku maupun kognitif. Kuatnya ikatan emosional antara remaja dengan ibu ditunjukkan melalui cara halus berupa pengungkapan diri. Sedangkan menurut Dewi \& Valentina (2013), kelekatan remaja terhadap ibu ditunjukkan dengan adanya komunikasi yang baik dan kepercayaan antara orang tua dan remaja.

Dampak dari kelekatan anak yang tidak aman terhadap ibu akan berpengaruh hingga usia perkembangan selanjutnya. Collins \& Read (1990) menemukan 


\section{ATTACHMENT TO MOTHER, ADJUSTMENT, ADOLESCENT OF PHYSICAL DISABILITY}

pengalaman tentang pengasuh anak waktu kecil berhubungan dengan perasaan aman di masa dewasa. Selain itu penelitian Mikulincer \& Shaver (2007) menemukan kepribadian anak yang mengalami kelekatan yang tidak aman di masa depannya menjadi sulit untuk mengungkapkan kekurangan dirinya. Shaver \& Clark (1994) menemukan bahwa bayi yang mengalami cemas dan ambivalen sangat ekspresif terhadap kemarahan. Bayi yang mengalami cemas ambivalen juga lebih cenderung mengekspresikan kecemasan dan kesusahan. Selain itu ditemukan bahwa kondisi bayi yang cemas dan ambivalen akan berpengaruh hingga usia remaja dan nantinya memiliki kelekatan yang cemas dan cenderung menghindar. Kelekatan remaja yang cemas mengakibatkan tingkat kemarahan, permusuhan, dan emosi negatif yang lebih tinggi.

Beberapa penelitian berhasil mengungkap pentingnya kelekatan terhadap ibu dan penyesuaian pada remaja. Penelitian pertama mengenai kelekatan dan resiliensi yang dilakukan oleh Atwool (2006) menunjukkan tingkat keterasingan yang rendah memungkinkan individu untuk berani memasuki lingkungan baru, sehingga individu memiliki penerimaan yang positif terhadap suatu perubahan dan hubungan yang dekat dengan orang lain, serta kemampuan adaptasi yang baik saat menemui masalah atau perubahan-perubahan spontan. Selain itu, studi yang dilakukan oleh Doyle (2000) menunjukkan bahwa kelekatan yang aman antara orang tua dengan remaja akan berdampak pada keberhasilan dalam menjalankan proses perubahan yang dialami di lingkungan dan menikmati hubungan yang lebih positif dengan keluarga dan teman sebaya. Kelekatan yang aman antara remaja dengan ibu menunjukkan sedikit kecemasan, kesendirian, dan penolakan sosial. Remaja dengan kelekatan aman akan menerapkan strategi coping yang lebih baik dibandingkan dengan remaja yang kelekatannya tidak aman. Penelitian terakhir tentang kelekatan dan penyesuaian diri pada remaja dilakukan oleh Fanti (2005) dengan subjek mahasiswa semester awal, yang menunjukkan bahwa hubungan remaja terutama dengan ibu dapat membantu mahasiswa menyesuaikan diri dengan kehidupan baru di dalam kampus. Ibu merupakan pendukung utama menghadapi stres tahun pertama mereka kuliah.

Berdasarkan penjelasan di atas, diprediksi bahwa kelekatan terhadap ibu dapat digunakan sebagai strategi dalam berinteraksi sosial bagi remaja disabilitas fisik. Kelekatan yang aman terhadap ibu akan membantu remaja dalam memahami berbagai situasi yang ada. Remaja dengan disabilitas fisik yang memiliki hubungan erat dengan anggota keluarganya, terutama ibu, sebagai figur pengasuh yang utama, menghasilkan pengaruh negatif dari lingkungannya. Hal ini menyebabkan remaja disabilitas fisik mampu memiliki ketahanan dan strategi coping yang baik sehingga dapat melakukan penyesuaian diri di masyarakat.

Melihat beberapa penelitian yang telah dilakukan sebelumnya mengenai kelekatan terhadap penyesuaian diri remaja, peneliti ingin menindaklanjuti permasalahan yang sama namun berbeda dengan sebelumnya. Perbedaan tersebut antara lain, pertama menggunakan subjek disabilitas fisik. Kedua, variabel yang digunakan dalam penelitian ini yaitu variabel bebas $(X)$ kelekatan remaja terhadap ibu dan variabel terikat $(\mathrm{Y})$ penyesuaian diri. Ketiga, subjek dan lokasi penelitian yang digunakan dalam penelitian ini juga berbeda. Berdasarkan uraian di atas, dapat dirumuskan masalah yang akan diangkat dalam penelitian ini adalah hubungan 


\section{Cognicia}

http://ejournal.umm.ac.id/index.php/cognicia
ISSN 2658-8428

, Vol. , No. , -

kelekatan terhadap ibu dan penyesuaian diri pada remaja disabilitas fisik. Tujuan dari penelitian ini adalah untuk mengetahui hubungan kelekatan terhadap ibu dan penyesuaian diri pada remaja disabilitas fisik. Manfaat penelitian ini adalah untuk mengetahui gambaran kelekatan remaja terhadap ibu serta mengetahui hubungan pada penyesuaian diri remaja disabilitas fisik sehingga hasil penelitian ini dapat digunakan sebagai salah satu acuan untuk mengadakan program penyuluhan atau psikoedukasi mengenai hubungan kelekatan terhadap ibu dan penyesuaian diri pada remaja disabilitas fisik.

Adapun hipotesis dalam penelitian ini yaitu terdapat hubungan positif yang signifikan antara kelekatan terhadap ibu dan penyesuaian diri pada remaja disabilitas fisik. Semakin tinggi kelekatan terhadap ibu semakin tinggi pula penyesuaian diri pada remaja disabilitas fisik dan sebaliknya.

\section{METODE}

Penelitian ini menggunakan pendekatan kuantitatif, yang merupakan pendekatan dengan data yang dapat diolah menggunakan statistik. Desain penelitian yang digunakan dalam penelitian ini adalah kuantitatif korelasional. Menurut Sugiono (2015), metode korelasi adalah metode pertautan atau metode penelitian yang berusaha menghubungkan antara satu unsur dengan unsur lain untuk menciptakan bentuk dan wujud baru yang berbeda dengan sebelumnya.

Menurut Winarsunu (2009), populasi yaitu seluruh individu yang dimaksudkan diteliti dan nanti digeneralisasikan. Sampel adalah bagian dari jumlah serta karakteristik yang dimiliki populasi tersebut (Sugiyono, 2015). Pengambilan sampel pada penelitian ini menggunakan total sampling, yaitu teknik pengambilan sampel dimana jumlah sampel sama dengan populasi (Sugiyono, 2015). Lokasi penelitian ini bertempat di 3 sekolah, yaitu SMALB Yayasan Putra Pancasila Malang, SMAK dan SMPK Bhakti Luhur Malang. Adapun kriteria subjek di antaranya merupakan remaja dengan karakteristik:

1. Remaja usia 12-21 tahun, berjenis kelamin laki-laki dan perempuan.

2. Mengalami disabilitas fisik (tunadaksa, tunanetra, tunarungu, atau tunawicara).

3. Memiliki ibu kandung dan pernah hidup bersama.

4. Mampu berkomunikasi dan bersedia menjadi responden penelitian.

Penelitian ini menggunakan dua variabel, yakni variabel bebeas $(X)$ dan variabel terikat $(\mathrm{Y})$. Adapun yang menjadi variabel bebas $(\mathrm{X})$ (independent variable) adalah kelekatan remaja terhadap ibu dan variabel terikatnya $(\mathrm{Y})$ (dependent variable) adalah penyesuaian diri.

Penyesuaian diri adalah kemampuan remaja keterbatasan fisik untuk dapat menyesuaiakan diri sesuai dengan kondisi lingkungan, yang dapat ditunjukkan dengan adanya penilaian terhadap kenyataan, kemampuan mengatasi tekanan dan ketegangan, gambaran diri yang baik, kemampuan mengungkapkan perasaan yang baik, dan memiliki hubungan dengan orang lain yang baik. Penyesuaian diri diukur dengan skala yang dikembangkan oleh peneliti sebanyak 50 item menurut teori Haber \& Runyon (1984). Alasan pembuatan alat ukur ini adalah aspek sesuai dengan konteks 


\section{ATTACHMENT TO MOTHER, ADJUSTMENT, ADOLESCENT OF PHYSICAL DISABILITY}

penelitian. Kebanyakan alat ukur lainnya tidak mengambarkan secara detail aspek dari penyesuain diri, hanya berupa aspek penyesuaian diri sendiri dan lingkungan sosial.

Kelekatan adalah ikatan perasaan antara remaja keterbatasan fisik terhadap ibu yang terbentuk sejak kecil, yang memiliki arti khusus bagi remaja keterbatasan fisik itu sendiri dan dapat ditunjukkan dengan adanya kepercayaan, komunikasi, dan perasaan tidak aman. Instrumen penelitian menggunakan skala kelekatan ibu disusun dari Inventory of Parent and Peer Attachment milik Armsden \& Greenberg (1987), yang berasal dari 3 jenis skala IPPA; IPPA-Mother, IPPA-Father, IPPA-Peer. Penelitian ini hanya menggunakan skala IPPA-M yang terdiri dari 25 item kelekatan ibu yang memiliki tingkat validitas 0,66-0,86. Selanjutnya dikembangkan lagi oleh peneliti dengan versi bahasa Indonesia.

Kedua alat ukur ini menggunakan skala likert, yakni skala yang telah disusun sebelumnya dengan kemudian diberikan kepada responden untuk diisi sesuai dengan indikator yang ada. Dalam penyusunannya, skala likert berisikan poin yang menunjukkan sangat setuju (SS), setuju (S), tidak setuju (TS), sangat tidak setuju (STS). Item pernyataan terdiri dari item-item sub skala yang bersifat favourable, yaitu yang mendukung terhadap sub skala yang diungkap dan unfavourable, yaitu yang bertentangan dengan sub skala yang diungkap. Secara jelas dirincikan sebagai berikut: Sangat setuju pada favorable diberikan nilai 4 dan unfavorable nilai 1 , setuju pada favorable diberikan nilai 3 dan unfavorable nilai 2, tidak setuju pada favorable diberikan nilai 2 dan unfavorable nilai 3, dan sangat tidak setuju pada favorable diberikan nilai 1 dan unfavorable nilai 4.

Tabel 1. Indeks Validitas dan Reliabilitas Alat Ukur Penelitian

\begin{tabular}{lccc}
\hline \multicolumn{1}{c}{ Alat Ukur } & Jumlah Item & Indeks & $\begin{array}{c}\text { Indeks } \\
\text { Reliabilita }\end{array}$ \\
& Valid & Validitas & s \\
\hline Kelekatan terhadap Ibu & 21 item & $0,368-0,817$ & 0,91 \\
Penyesuaian Diri & 35 item & $0,382-0,748$ & 0,928 \\
\hline
\end{tabular}

Berdasarkan hasil uji validitas dan reliabilitas alat ukur kelekatan ibu dan penyesuaian diri, pada skala kelekatan terhadap ibu, dari 25 item, terdapat 4 item yang tidak valid, sehingga tersisa 21 item valid yang dapat digunakan. Indeks validitas alat ukur kelekatan ibu berada pada rentang 0,368 - 0,817 dan tingkat reliabilitas sebesar 0,91 . Sedangkan pada skala penyesuaian diri, dari 50 item terdapat 15 item tidak valid dan tersisa 35 valid yang dapat digunakan untuk mengukur tingkat penyesuaian diri subjek. Indek validitas berada pada rentang 0,382 - 0,748 dan nilai $\mathrm{r}$ tabel 0,361.

Penelitian ini memiliki empat prosedur utama sebagai berikut: Pertama, tahap persiapan dimulai dari peneliti melakukan pendalaman materi melalui kajian teoritik dilanjutkan dengan penyusunan proposal, kemudian peneliti membuat alat ukur berdasarkan aspek variabel, selanjutnya meminta ijin melakukan penelitian (pengambilan data) kepada instansi yang dituju. Peneliti mempersiapkan pelaksanaan try out. Instrumen penelitian berupa skala yang selesai diadaptasi oleh peneliti. Skala 


\section{Cognicia}

http://ejournal.umm.ac.id/index.php/cognicia
ISSN 2658-8428

, Vol. , No. , -

yang digunakan terdiri dari dua jenis, yaitu skala kelekatan remaja terhadap ibu dan skala penyesuaian diri.

Setelah itu peneliti melakukan try out. Peneliti mengambil data kepada remaja dengan disabilitas fisik di Kota Malang, tepatnya di UPT Rehabilitasi Sosial Cacat Netra Malang dengan jumlah subjek 30 remaja disabilitas fisik netra, dengan karakteristik memiliki ibu kandung, berusia remaja, dapat berkomunikasi. Kemudian peneliti melakukan analisis data menggunakan SPSS untuk mendapatkan item valid dan reliabel. Berdasarkan hasil uji validitas dan reabilitas pada skala kelekatan ibu, didapat nilai reabilitas 0,910 dengan 4 item gugur, sehigga keseluruhan item berjumlah valid 21 item. Sedangkan pada skala penyesuaian diri, didapatkan nilai reabilitas 0,928 dengan 15 item gugur, sehingga menyisakan jumlah item valid sebesar 35 item.

Kedua, yakni tahap pelaksanaan. Pada tahap ini, peneliti melakukan penyebaran skala pada 56 remaja disabilitas fisik bertempat di tiga sekolah. Ketiga sekolah tersebut adalah SMALB Yayasan Putra Pancasila Malang, SMPK Bhakti Luhur Malang, dan SMAK Bhakti Luhur Malang. Peneliti memberikan dua skala, skala kelekatan remaja terhadap ibu dan skala penyesuaian diri dengan item yang telah valid dan reliabel. Dalam proses pengambilan data, peneliti menyesuaikan dengan keadaan subjek disabilitas fisik. Bagi subjek yang mengalami disabilitas fisik tunanetra dan tunadaksa, peneliti melakukan pengambilan data dengan membacakan isi kuesioner dan menuliskan jawaban subjek di lembar kuesioner, sedangkan subjek yang mengalami disabilitas fisik tunarungu atau tunawicara, bagi subjek yang dapat membaca dan tidak mengalami kesulitan bahasa, pengisian kuesioner dilakukan sendiri tanpa bantuan peneliti. Bagi subjek yang mengalami kesulitan bahasa, pada saat pengisian kuesioner subjek akan didampingi dan dibantu guru pendamping.

Tahap terakhir yaitu peneliti melakukan entry data untuk dianalisis. Analisis data menggunakan perhitungan secara statistik program SPSS (Statistical Program for Social Science) for Windows (SPSS 21), yaitu analisis parametrik. Analisis yang digunakan untuk menguji hubungan kelekatan terhadap ibu dan penyesuaian diri pada remaja disabilitas fisik adalah ui korelasi product moment person.

\section{HASIL}

Subjek dalam penelitian ini adalah remaja disabilitas fisik berusia 12-21 tahun yang memiliki ibu kandung. Total subjek dalam penelitian ini adalah 56 orang. Data demografis subjek penelitian digambarkan pada tabel 2:

Tabel 2. Deskripsi Subjek

\begin{tabular}{lcc}
\hline \multicolumn{1}{c}{ Kategori } & Frekuensi & Persentase \\
\hline Jenis Kelamin & & \\
Laki-Laki & 29 & $52 \%$ \\
Perempuan & 27 & $48 \%$ \\
Usia & & \\
$\quad$ Remaja Awal (12-15 th) & 4 & $7 \%$ \\
Remaja Madya (15-18 th) & 20 & $36 \%$ \\
Remaja Akhir (18-21 th) & 32 & $57 \%$
\end{tabular}




\begin{tabular}{lcc} 
Lama Disabilitas Fisik & & \\
$<5$ Tahun & 7 & $13 \%$ \\
$>5$ Tahun & 3 & $5 \%$ \\
Sejak Lahir & 46 & $82 \%$ \\
Jenis Disabilitas Fisik & & \\
Tunadaksa & 6 & $11 \%$ \\
Tunanetra & 33 & $59 \%$ \\
Tunarungu/Tunawicara & 17 & $30 \%$ \\
\hline
\end{tabular}

Berdasarkan tabel 2, jika ditinjau dari jenis kelamin, jumlah subjek laki-laki lebih tinggi daripada subjek berjenis kelamin perempuan dengan perbedaan persentase sebesar $2 \%$. Ditinjau dari kategori rentang usia remaja, jumlah subjek tertinggi berada pada rentang usia sejak akhir, diikuti rentang usia remaja madya, dan terendah rentang usia remaja awal. Selanjutnya jumlah subjek ditinjau dari lama disabilitas fisik, jumlah subjek tertinggi berada pada rentang usia sejak lahir, diikuti jumlah subjek $<5$ tahun, dan terakhir $>5$ tahun. Selain itu penyebab disabilitas fisik yang bukan berasal dari sejak lahir dipengaruhi berbagai faktor-faktor antara lain; pola hidup yang tidak sehat, minum alkohol, sakit glukoma, otot mata yang mulai melemah, overdosis obat, dan kecelakaan. Terakhir ditinjau dari jenis disabilitas fisik, jumlah subjek disabilitas fisik tertinggi berada pada jenis disabilitas fisik tunanetra, diikuti jenis disabilitas fisik tunarungu atau tunawicara, dan terendah berada pada jenis disabilitas fisik tunadaksa.

Tabel 3. Deskripsi Uji Korelasi Product Moment Pearson

\begin{tabular}{llrr}
\hline & & \multicolumn{2}{c}{ Kelekatan } \\
terhadap Ibu & Penyesuaian Diri \\
\hline Kelekatan ibu & Pearson Correlation & 1 & 0,815 \\
& Sig. (1-tailed) & & 0,000 \\
Penyesuaian Diri & Pearson Correlation & 0,815 & 1 \\
& Sig. (1-tailed) & 0,000 & \\
\hline
\end{tabular}

Dari hasil uji korelasi diketahui bahwa $\mathrm{p}=0,000$ terdapat hubungan yang positif yang signifikan, artinya semakin tinggi skor kelekatan remaja dengan ibu maka semakin tinggi pula skor penyesuaian diri pada remaja disabilitas fisik. Nilai koefisien korelasi antara kelekatan remaja dengan ibu dan penyesuaian diri adalah sebesar $\mathrm{r}=$ 0,815 ( $\mathrm{p}<0,05$ ), artinya kekuatan hubungan antara variabel sebesar 0,815 . Adanya hubungan kelekatan remaja dengan ibu dan penyesuaian diri, maka hipotesis diterima, dengan kata lain terdapat hubungan positif yang signifikan antara kelekatan remaja dengan ibu dan penyesuaian diri pada remaja disabilitas fisik.

Selanjutnya dari analisis yang telah dilakukan, diketahui bahwa nilai koefisien determinan variabel $\left(\mathrm{r}^{2}\right)$ adalah 0,665 atau sebesar 66,5\%. Artinya bahwa kelekatan remaja dengan ibu memiliki sumbangan terhadap penyesuaian diri sebesar $66,5 \%$. Sedangkan sisanya sebanyak 33,5 dipengaruhi oleh faktor lain.

Tabel 4. Perhitungan Skor Skala Kelekatan Remaja dengan Ibu 
Cognicia

http://ejournal.umm.ac.id/index.php/cognicia
ISSN 2658-8428

, Vol. , No.

\begin{tabular}{cccc}
\hline Kelekatan Ibu & Interval & Frekuensi & Persentase \\
\hline Tinggi & $\mathrm{T} \geq 50,00$ & 27 & $48 \%$ \\
Rendah & $\mathrm{T}<50,00$ & 29 & $52 \%$ \\
\hline Total & & 56 & $100 \%$ \\
\hline
\end{tabular}

Berdasarkan tabel 4, dapat diketahui bahwa nilai rata-rata dari skala kelekatan remaja dengan ibu adalah 50,00. Dari 56 jumlah subjek remaja disabilitas fisik, ditemukan bahwa sebanyak 29 subjek memiliki kelekatan rendah sebesar 52\% dan 27 subjek dengan persentase $48 \%$ memiliki nilai kelekatan yang tinggi. Diambil kesimpulan bahwa mayoritas subjek disabilitas fisik memiliki kelekatan yang rendah dengan perbedaan persentase rendah dan tinggi sebesar $2 \%$.

Tabel 5. Perhitungan Skor Skala Penyesuaian Diri

\begin{tabular}{cccc}
\hline Penyesuaian diri & Interval & Frekuensi & Persentase \\
\hline Tinggi & $\mathrm{T} \geq 50,00$ & 24 & $43 \%$ \\
Rendah & $\mathrm{T}<50,00$ & 32 & $57 \%$ \\
\hline Total & & 56 & $100 \%$ \\
\hline
\end{tabular}

Berdasarkan tabel 5, dapat diketahui bahwa nilai rata-rata dari skala penyesuaian diri adalah 50,00. Dari 56 jumlah subjek remaja disabilitas fisik, ditemukan bahwa sebanyak 24 subjek dengan persentase $43 \%$ memiliki nilai penyesuaian diri yang tinggi dan 32 subjek dengan persentase $57 \%$ memiliki nilai penyesuaian diri yang rendah. Diambil kesimpulan bahwa mayoritas subjek disabilitas fisik memiliki penyesuaian diri yang rendah dengan perbedaan persentase rendah dan tinggi sebesar $14 \%$.

Tabel 6. Kategorisasi Tingkat Kelekatan terhadap Ibu dan Penyesuaian Diri

\begin{tabular}{cccccc}
\hline Kategori & $\begin{array}{c}\text { Frekuens } \\
\text { i }\end{array}$ & Kelekatan ibu & \multicolumn{2}{c}{$\begin{array}{c}\text { Penyesuaian diri } \\
\text { Tingg }\end{array}$} & \\
& & Tinggi & Rendah & i & Rendah \\
\hline Jenis Disabilitas Fisik & & & & & \\
Tunadaksa & 6 & $33 \%$ & $67 \%$ & $17 \%$ & $83 \%$ \\
Tunanetra & 33 & $64 \%$ & $36 \%$ & $45 \%$ & $55 \%$ \\
Tunarungu/ tunawicara & 17 & $24 \%$ & $76 \%$ & $29 \%$ & $71 \%$ \\
\hline
\end{tabular}

Berdasarkan kategorisasi tingkat kelekatan terhadap ibu dan penyesuaian ditinjau dari jenis disabilitas fisik, tingkat kelekatan remaja dan ibu tertinggi berada pada subjek tunanetra dengan persentase tinggi $64 \%$ selanjutnya disabilitas fisik tunadaksa dengan persentase tinggi 33\%, dan terendah berada pada subjek disabilitas fisik tunarungu dengan persentase tinggi $24 \%$. Sedangkan pada tingkat penyesuaian diri subjek disabilitas fisik, memiliki penyesuaian diri tertinggi berada pada subjek tunanetra dengan persentase tinggi $45 \%$, diikuti tunarungu dengan persentase tinggi $29 \%$ dan terendah berada pada subjek tunadaksa dengan persentase tinggi $17 \%$. 


\section{ATTACHMENT TO MOTHER, ADJUSTMENT, ADOLESCENT OF PHYSICAL DISABILITY}

\section{DISKUSI}

Dari penelitian yang telah dilakukan, didapatkan hasil bahwa terdapat hubungan positif yang signifikan antara kelekatan terhadap ibu dan penyesuaian diri pada remaja disabilitas fisik $(r=0,815, p<0,05)$. Data tersebut menunjukkan semakin tinggi kelekatan remaja terhadap ibu, maka semakin tinggi pula penyesuaian diri pada remaja disabilitas fisik, sebaliknya semakin rendah kelekatan remaja terhadap ibu, maka semakin rendah pula penyesuaian remaja pada disabilitas fisik. Hasil penelitian ini membuktikan hipotesis dalam penelitian yang menyatakan bahwa ada hubungan positif yang signifikan antara kelekatan terhadap ibu dan penyesuaian diri pada remaja disabilitas fisik dapat diterima. Dengan terbuktinya hipotesis, maka terbukti bahwa kelekatan remaja terhadap ibu dapat meningkatkan penyesuaian diri pada remaja disabilitas fisik.

Sejalan dengan pernyataan Allen \& Kuperminc dkk (2004) yang mengungkapkan kelekatan remaja dengan ibu akan mampu memfasilitasi remaja dalam kecakapan dan kesejahteraan, seperti yang tercermin dalam beberapa ciri seperti harga diri, penyesuaian emosi, dan kesehatan fisik. Diperkuat dengan penelitian sebelumnya oleh Izzah (2017) dengan subjek remaja menunjukkan terdapat hubungan yang signifikan antara gaya kelekatan antara orang tua dan harga diri pada remaja. Kelekatan yang aman terhadap ibu akan meningkatkan harga diri. Sedangkan harga diri digunakan remaja disabilitas fisik dalam melakukan penyesuaian dirinya. Diperkuat penelitian sebelumnya oleh Al-Kharimah (2015) yang menunjukkan terdapat hubungan yang positif secara signifikan antara harga diri, subjective well-being, dan penyesuaian pada penyandang tunadaksa.

Penelitian ini menemukan bahwa sebagian remaja disabilitas fisik memiliki kelekatan yang tinggi terhadap ibunya. Hermasanti (2009) mengatakan faktor-faktor yang memengaruhi kelekatan antara ibu dengan anak, yaitu aspek utama pembentukan dan pengembangan kelekatan adalah penerimaan figur lekat, sensitivitas atau kepekaan figur lekat terhadap kebutuhan individu dan responsivitas kedua belah pihak, baik figur lekat maupun individu dalam menanggapi stimulus yang diberikan untuk memperkuat kelekatan antara keduanya. Darling (1982) menyatakan bahwa sejalan dengan bertambahnya usia anak dan kedewasaan orang tua, maka sikap yang ditampakkan orang tua pada anaknya yang cacat adalah mampu menerima kecacatan yang dialami sang anak dan menyadari hal tersebut merupakan suatu kenyataan yang tidak dapat dipungkiri. Dengan demikian penerimaan ibu juga akan memengaruhi tingkat kelekatannya. Ibu yang menerima kondisi dan mulai sering merespon anak disabilitas fisiknya, dengan demikian juga akan meningkatnya kelekatan ibu dengan anak.

Penelitian ini menunjukkan bahwa kelekatan remaja dengan ibu paling rendah berada pada disabilitas fisik jenis tunarungu dengan persentase rendah $76 \%$. Menurut Baradja (2009), beberapa faktor yang memengaruhi tingkat kelekatan seorang anak pada figur lekatnya adalah adanya rasa puas seorang anak pada pemberian figur lekat, terjadi reaksi atau merespon setiap tingkah laku yang menunjukkan perhatian, dan 


\section{Cognicia}

http://ejournal.umm.ac.id/index.php/cognicia
ISSN 2658-8428

, Vol. , No. , -

seringnya figur lekat melakukan proses interaksi dengan anak. Diperkuat dengan penelitian Howe (2006) bahwa orang tua jauh lebih sulit mencapai kepekaan dan mengenali keadaan anak yang memiliki kecacatan dalam berkomunikasi.

Laumi \& Adiyanti (2012) menemukan bahwa ketika komunikasi tidak terjalin dengan baik, anak akan merasa dikucilkan oleh orang tua sehingga mengurangi rasa aman mereka. Hal ini secara berangsur-angsur akan menghilangkan rasa kepercayaan mereka pada orang tua. Berdasarkan penelitian oleh Purnama \& Wahyuni (2017), pengucilan dari ibu dan ayah mempunyai hubungan yang negatif dengan kompetensi sosial pada remaja. Perasaan dikucilkan dari ibu dan ayah dapat membuat remaja sulit dalam berinteraksi dengan orang lain dan akan cenderung menjadi pribadi yang narsistik dan kurang mampu dalam menjalin interaksi sosial.

Keadaan cacat fisik ditandai oleh adanya cacat atau kelainan fungsi pada jasmaninya. Keadaan ini menghambat perkembangan, mempersukar tingkah lakunya dan berpengaruh kepada perkembangan kepribadiannya. Anak cacat biasanya disebut anak luar biasa, yaitu anak yang dalam proses perkembangan dan pertumbuhannya mengalami penyimpangan bila dibandingkan dengan anak normal yang sebaya (Walgito, 1983). Bagaimana anak bereaksi terhadap cacat tubuhnya, akan menentukan apa pengaruhnya terhadap kemampuannya dalam penyesuaian pribadi dan sosial (Hurlock, 1990).

Penyelidikan dampak buruk kecacatan fisik masa kanak-kanak diketahui bahwa anak-anak yang memiliki cacat fisik kronis dua kali lebih mungkin mengalami gangguan emosional sekunder daripada anak-anak yang sehat secara fisik (Eiser, 1990). Penelitian ini juga menemukan bahwa kelekatan remaja dengan ibu pada remaja disabilitas fisik, didominasi remaja yang memiliki kelekatan rendah sebesar $52 \%$. Hasil ini sesuai dengan penelitian sebelumnya menemukan bahwa anak-anak penyandang cacat lebih cenderung diklasifikasikan sebagai terpasang dengan tidak aman (Clements \& Barnett, 2002). Dalam penelitiannya, Moniaga (2003) menemukan persepsi dan tindakan orang tua maupun orang lain juga akan mempengaruhi remaja disabilitas dalam membentuk konsep dirinya. Remaja memandang dirinya berdasarkan bagaimana mereka diperlakukan dan dipandang oleh orang lain.

Fakta lain ditemukan jenis disabilitas fisik tunadaksa memiliki tingkat penyesuaian diri paling rendah dengan persentase rendah $83 \%$. Schneiders (dalam Ali, 2012) mengemukakan faktor yang mempengaruhi penyesuaian diri salah satunya adalah kondisi fisik. Penyesuaian diri akan lebih mudah dilakukan dalam kondisi fisik yang sehat daripada yang tidak sehat. Kondisi fisik yang tidak sehat adanya kecacatan fisik dapat menimbulkan penyesuaian diri, percaya diri, dan harga diri yang rendah. Kondisi ini merugikan dalam proses penyesuaian diri.

Penelitian lain yang mendukung hasil penelitian ini dilakukan oleh Aslan (2010), yang menunjukkan ada hubungan positif yang signifikan antara kelekatan dan penyesuaian pada masa remaja akhir. Remaja dengan kelekatan yang aman akan cenderung mampu menyesuaikan diri daripada remaja dengan kelekatan tidak aman. Penelitian lainnya oleh Syarifa \& Indrawati (2017) membuktikan, kelekatan aman terhadap ibu dan penyesuaian diri pada subjek mahasiswa menunjukkan bahwa kelekatan aman terhadap ibu memberikan sumbangan efektif sebesar $31 \%$ pada 


\section{ATTACHMENT TO MOTHER, ADJUSTMENT, ADOLESCENT OF PHYSICAL DISABILITY}

penyesuaian diri. Hasil tersebut munujukkan keselarasan dengan hasil penelitian ini yang menunjukkan adanya hubungan positif yang signifikan antara kelekatan remaja terhadap ibu dan penyesuaian diri.

Dalam penelitian ini tidak dipungkiri adanya kelemahan. Berbagai keterbatasan juga muncul, terutama terbatasnya penelitian-penelitian sebelumnya yang berhubungan antara kelekatan orang tua dengan disabilitas fisik. Selain itu, tidak seimbainya jumlah subjek disabilitas akan mempengaruhi tingkat validitas dan reabilitas. Ada pula beberapa subjek yang kesulitan memahami isi skala sehingga seringkali terjadi kekosongan jawaban dan melakukan pengulangan pengisian. Terdapat beberapa subjek yang menolak untuk untuk menjadi responden penelitian. Skala yang digunakan di dalam penelitian ini adalah skala yang diadaptasi dari jurnal internasional yang diterjemahkan dan disesuaikan dengan kondisi di Indonesia.

\section{SIMPULAN DAN IMPLIKASI}

Berdasarkan hasil penelitian ini didapatkan kesimpulan bahwa terdapat hubungan positif yang signifikan antara kelekatan terhadap ibu dan penyesuaian diri pada remaja disabilitas fisik. Artinya semakin tinggi tingkat kelekatan remaja dengan ibu, maka semakin tinggi tingkat penyesuaian diri pada remaja disabilitas fisik ( $\mathrm{r}=$ $0,815 ; \mathrm{p}=0,000)$. Selain itu sumbangan efektif dari kelekatan remaja dengan ibu tehadap penyesuaian diri pada remaja disabilitas fisik sebesar $66,5 \%$.

Implikasi dari penelitian ini adalah bagi remaja disabilitas fisik yang memiliki kelekatan dan penyesuaian diri yang rendah diharapkan dapat terbuka lagi, menjalin dan meningkatkan komunikasi dengan orang tua, selalu berpikir positif dan menerima secara positif terhadap diri sendiri, terhadap orang tua maupun perlakuan orang lain, meningkatkan peran aktif dalam kehidupan masyarakat dan memperluas pergaulan sosialnya.

Bagi keluarga disabilitas fisik disarankan bagi orang tua untuk meningkatkan penerimaan pada sang anak dan memperlakukannya dengan cara yang baik. Hal tersebut sebagai salah satu cara untuk menjalin kelekatan yang baik dengan anak. Selain itu, meningkatkan kelekatan dalam bentuk komunikasi, kepercayaan, dukungannya, memberikan motivasi yang positif pada remajanya sehingga dengan hal tersebut akan meningkatkan harga diri dan kompetensi sosial pada anak disabilitas fisik yang mana akan mempermudah anak dalam melakukan penyesuaian diri kelak dimasyarakat.

Bagi peneliti selanjutnya diharapkan dapat melanjutkan penelitian ini dengan menggunakan variabel kelekatan, sampel, dan lokasi yang berbeda dengan penelitian ini. Hal tersebut diharapkan dapat memperkaya terkait variabel yang diteliti.

\section{REFERENSI}

Ahmad, B. K., \& Zadeh Z. F. (2014) Gender discrimination in disabled adolescents: An analysis of psychological adjustment in a cosmopolitan city in pakistan. Journal Sociology and Anthropolgy, 2, (6), 232-238.

Agustiani, H. (2006). Psikologi perkembangan: Pendekatan ekologi kaitannya dengan konsep diri dan penyesuain diri pada remaja. Bandung: PT. Refika Aditama. 


\section{Cognicia}

http://ejournal.umm.ac.id/index.php/cognicia
ISSN 2658-8428

, Vol. , No. , -

Al-Mighwar, M. (2006). Psikologi remaja petunjuk bagi guru dan orang tua. Bandung : CV Pustaka Setia.

Al-karimah, N. F. (2015). Hubungan antara penyesuaian diri dan harga diri dengan subjective well being. Tesis, Fakultas Psikologi, Universitas Muhammadiyah, Surakarta.

Ali, M., \& Asrori, M. (2012). Psikologi remaja perkembangan peserta didik Cetakan Ketujuh. Jakarta: PT Bumi Aksara.

Allen, J. P., \& Land, D. (1999). Attachment in adolescence. In Cassidy \& P. R. Shaver (Eds.), Handbook of attachment theory and research. New York: Press.

Allen, J. P., Mcelhaney, K. B., \& Kuperminc, G. P. (2004). Stability and change in attachment security across adolescence. Child Development, 75, (6), 1792-1805.

Aslan, S. (2010). The relation between attachment and personal and social. adjustment mediated by separation-individuation. Procedia Social and Behavioral Sciences. 4048-4053.

Atwool, N. (2006). Attachment and resilience: Implications for children in care. Child Care in Practice, 12, 315-330.

Badan Pusat Statistik (BPS) Kota Malang. (2016). Jumlah Penyandang Masalah Kesejahteraan Sosial (PMKS) Menurut Jenis Kelamin Di Kota Malang. Accessed on February 1, 2018, from https://malangkota.bps.go.id/statictable/2017/07/24/606/jumlah penyandang-masalahkesejahteraan-sosial-pmks-menurut-jenis-kelamin-di-kota-malang-tahun-2016.html.

Baradja, A. (2005). Psikologi perkembangan : Tahapan-tahapan dan aspek-aspeknya. Jakarta: Studia Press.

Barrocas, A. L. (2009). Adolescent attachment to parents and peers: The emory center for myth and ritual in american life. Working Paper, 50. Accessed on Januari 16, 2017, from https:// www.slideshare.net/gaz12000/adolescent-attachment-to-parents-and-peers.

Berk, L. E. (2005). Infants, children, and adolescence. 5th Ed. America : Pearson Education, Inc.

Brooks-Gunn, J., \& Lewis, M. (1982). Affective exchanges between normal and handicapped infants and their mothers. In T. Field, \& A. Fogel (Eds.), emotion and interaction: Normal and high risk infants. Hillsdale: NJ, Erlbaum.

Collins N. L., \& Read S. J. (1990) Adult attachment, working models, and relationship quality in dating couples. Journal of Personality and Social Psychology, 58, 644-663.

Clements, M., \& Barnett, D. (2002). Parenting and attachment among toddlers with congenital anomalies. Infant Mental Health Journal, 23, 625-642.

Darling, D. (1982). Children who are different meeting the challenges of birth defects in society. London : C.V. Mosby Company.

De Minzi, M. (2010). Gender and cultural patterns of mothers' and fathers'attachment and links with children's self-competence, depression and loneliness in middle and late childhood. Early Child Development \& Care, 180, 193-209.

Departemen Pendidikan Nasional. (2008). Kamus Besar Bahasa Indonesia Pusat Bahasa. Jakarta: PT Gramedia Pustaka Utama.

Desmita, R. (2008). Psikologi perkembangan. Bandung: PT.Remaja Rosdakarya.

Dewi, A., \& Valentina, T. D. (2013). Hubungan kelekatan orang tua-remaja dengan kemandirian pada remaja di smkn 1 denpasar. Jurnal Psikologi Udayana, 1, (1), 181-189.

Doyle, A. B. (2000). Attachment to parents and adjusment in adolescence. Literature Review and Policy Implications, Concordia Univesity, Canada.

Eliasa, E. I. (2011). Pentingnya kelekatakan ibu dalam internal working model untuk pembentukan karakter anak. Skripsi, Fakultas Ilmu Pendidikan Universitas Negeri, Yogyakarta.

Enung, F. (2006). Psikologi perkembangan: Perkembangan peserta didik. Bandung: Pustaka Setia.

Eiser, C. (1990). Psychological effects of chronic disease. Journal of Child Psychology and Psychiatry, 31, 85-98. 


\section{ATTACHMENT TO MOTHER, ADJUSTMENT, ADOLESCENT OF PHYSICAL DISABILITY}

Fanti, K. A. (2005). The parent-adolescent relationtship and college adjustment over the freshman year. Psychology Theses, George State Universty, America.

Hair, E. C., Jager, J., \& Gartett S. (2001). Background for community-level work on social competency in adolescence: Reviewing the literature on contributing factors. Accessed 23 Desember, 2017 from $\quad$ https://www.childtrends.org/wp-content/uploads/2013/05/Background-forcommunity-level-work-on-social.pdf.

Hermasanti, W. (2009). Hubungan antara pola kelekatan dengan kecerdasan emosi pada Remaja siswa kelas xi sma negeri i karanganyar. Skripsi, Universitas Sebelas Maret, Surakarta.

Howe, D. (2006). Disabled children, parent-child interaction and sttachment: Child \& family social work. Journal Child \& Family Social Work, 11, (2), 95-106.

Hurlock, E. B. (1990). Psikologi perkembangan suatu pendekatan sepanjang rentang Kehidupan (Edisi 5). Jakarta : Penerbit Erlangga.

Izzah, I. (2017). Peranan gaya kelekatan kepada orang tua dengan harga diri pada remaja. Sosiologi Reflektif, 11, (2), 125-140.

Kartono, K. (2002). Psikologi umum. Bandung : Sinar Baru Algies Indonesia.

Kenny, M. E., \& Sirin, S. R. (2006). Parental attachment, self-worth, and depressive symptoms among emerging adults. Journal of Counseling and Development, 84, 61-71.

Kholis, R. N. (2013). Panduan anak berkebutuhan khusus. Yogyakarta: Imperium.

Laumi \& Adiyanti, M. G. (2012). Attachment of adolescent to mother, father, peer, with family structure as moderating variabel and their relationships with self esteem. Journal of Psychology, 39 (2), 129-142.

Liliana, A.W. (2009). Gambaran kelekatan remaja akhir putri dengan ibu. Skripsi, Fakultas Psikologi Universitas Gunadharma, Depok.

Lopez, S. (2013). Mother and father attachment relationships with children who have disabilities. Psychology Theses, Utah State University, Logan.

Ma, C. Q., \& Huebner, E. S. (2008). Attachment relationships and adolescents' life satisfaction: Some relationships matter more to girls than boys. Psychology in the Schools. 45, (2), 177190.

Mikulincer, M., \& Shaver, P. R. (2007). Attachment in adulthood structuredynamisc and change. New York: The Guildford Press.

Miranda, D. (2013). Strategi coping dan kelelahan emosional (emotional exhaustion) pada ibu yang memiliki anak berkebutuhan khusus (Studi kasus di rumah sakit jiwa daerah atma husada Mahakam). Jurnal Psikologi. 1, (2), 133-145.

Moniaga, Grace T. (2003). Gambaran konsep diri pada remaja penyandang sindroma down. Skirpsi, Depok: Fakultas Psikologi UI.

Monks, F. J., Knoers A. M. P., \& Haditono, S.R. (2006). Psikologi perkembangan: Pengantar dalam berbagai bagiannya. Yogyakarta: Gadjah Mada University Press.

Mu'tadin, Z. (2002). Mengembangkan keterampilan sosial pada remaja. Journal of Internet Psychology, Accesed on November 12, 2017 from http://www.epsikologi.com/remaja/060802.html.

Pasal 6 Peraturan Menteri Kesehatan Republik Indonesia Nomor: 104/MENKES/PER/II/1999.

Perkins, T., Holburn, S., Deaux, K., Flory, M., \& Vietze, P. (2002). Children of mothers with intellectual disability: stigma, mother-child relationship and self-esteem. Journal of Applied Research in Intellectual Disabilities, 15, 297-313.

Purnama, R. W., \& Wahyuni, S. (2017). Kelekatan (attachment) pada ibu dan ayah dengan kompetensi sosial pada remaja. Jurnal Psikologi, 13, (1), 32-40.

Ryan, R. M., \& Lynch, J. (1989). Emotional autonomy versus detachment revisiting the vicissitudes of adolescence and young adulthood. Child Development, 60, 340-356. 


\section{Cognicia}

http://ejournal.umm.ac.id/index.php/cognicia
ISSN 2658-8428

, Vol. , No. , -

Santrock, J. W. (2004, 2007, 2011). Remaja. Edisi 11 jilid 2 (Terj. Widyasinta Benedictine). Jakarta: Erlangga.

Shaver, P. R., \& Clark, C. (1994). The psychodynamics of adult romantic attachment. In J. M. Masling $\mathcal{E}$ R. F. Bornstein (Eds.), Empirical perspectives on object relations theory. Empirical studies of psychoanalytic theories, DC: American Psychological Association, Washington.

Sholeh, Akhmad. (2015). Islam dan penyandang disabilitas: telaah hak aksesibilitas penyandang disabilitas dalam sistem pendidikan di indonesia. Jurnal Palastren, Vol. 8, No. 2, 293-320.

Smojver-Ažić, S., Dorčić, T. M., \& Juretić J. (2015) Contribution of parental attachment and involvement to the academic, emotional and social adjustment to college: A three-year longitudinal study. Horizons of Psychology, 24, 21-32.

Steinberg, Lawrence. 2002. Adolescence (Sixth edition). New York: McGraw Hill Inc.

Sugiyono. (2015). Metode penelitian pendidikan: Pendekatan kuantitatif, kualitatif dan r\&d. Bandung: Alfabeta.

Suharmini, T. (2007). Psikologi anak berkebutuhan khusus. Jakarta: Depdiknas.

Syarifa, M., \& Indrawati E. S. (2017). Hubungan antara kelekatan aman terhadap ibu dan penyesuaian diri pada mahasiswa tahun pertama fakultas psikologi universitas diponegoro. Jurnal Empati, 6, (1), 276-280.

Thohari, S. (2014). Pandangan disabilitas dan aksesibilitas fasilitas publik bagi penyandang disabilitas di kota Malang. Indonesia Journal of Disabilities Studies, 1, 27-37.

Undang Undang Nomor 4 Tahun 1997 tentang Penyandang Cacat, Pasal 1.

Walgito, B. (1983). Bimbingan dan penyuluhan sekolah. Yogyakarta: Fakultas Psikologi UGM. . (2003). Pengantar psikologi umum. Yogyakarta: Yayasan Penerbitan Fakultas Psikologi UGM.

Widyastuti, N., \& Widjaja, T. (2004). Hubungan antara kualitas relasi ayah dengan harga diri remaja putra. Jurnal Psikologi, 2, (1), 22-43.

Willis, S. (1981). Problema remaja dan permasalahannya. Bandung: Angkasa.

Winarsunu, T. (2009). Statistik dalam penelitian psikologi dan pendidikan. Malang: UMM Press. 